\title{
厚生労働行政の立場からみた獣医疫学
}

\author{
宮川昭二 \\ 厚生労働省 食品安全部 監視安全課

\section{Epidemiology in Veterinary Public Health under MHLW Food Safety Administration}

\author{
Shoji MIYAKAWA
}

Inspection and Safety Division, Ministry of Health, Labour and Welfare

\begin{abstract}
Summary
The Ministry of Health, Labour and Welfare (MHLW) maintains the safety of food in Japan by enforcement of the laws relevant to food safety since prevention of foodborne disease is one of important part of public health.

According to the Statistics on Foodbourne Diseases, 1,545 events involved 27,019 cases and 7 deaths were reported in 2005. Meat and poultry meat tend to be contaminated with foodborne pathogens such as entrohaemorragic Escherichia coli (EHEC) and Salmonella spp. To prevent foodborne disease by those foods, collaboration with agricultural sector has been required. Furthermore increase of campylobacteriosis is remarkable during last few years and food implicated to the disease is mainly poultry meat. MHLW promotes to apply HACCP principle for control of foodborne pathogens in poultry processing plant on the assumption that poultry has been contaminated with campylobactor and other foodborne pathogens at poultry farm level. It also promotes to advise public that elderly and youth do not consume undercooked poultry meat.

Food safety administration under MHLW continues to ensure the safety of food in collaboration with other agencies for food production sector.
\end{abstract}

サルモネラや腸管出血性大腸菌などによる細菌性食中 毒への対応は, 獣医公衆衛生分野において, 従来から種々 の取り組みが行われてきた。厚生労働省では, 特にと畜場 での衛生管理や鶏卵などの規格基準の整備など, 食品衛 生法などによる規制を通じて, 食肉や鶏卵などの動物性 食品の安全性確保に努めてきた。

食品の安全に係る多くの課題については, これまでの 取り組みにより解決を果たしてきた実績がある一方, 例 えば, カンピロバクターによる食中毒などは, 依然として 食品安全の大きな艿威となっている。

○食品の安全性確保への新たな取り組み

我が国国内での BSE 発生などを背景に, 食品の安全を 巡る政府の取り組みは, 平成 15 年の食品安全基本法の公 布により, 大きな变革を遂げてきた。食品安全基本法によ り, 食品安全における取り組みにおいては, リスク分析手 法が取り入れられることとなり (下図), リスクに係る評
価は科学者で構成される食品安全委員会において実施す ることとなった。一方, 食品安全に係る管理 (規制) は, 行政府が行うこととなり, 食品の安全に係る規制である 食品衛生法の施行は厚生労働省が，農畜水産など生産段 階での規制である農薬取締法や飼料安全法などの施行は 農林水産省がそれぞれ行っている。

食品安全基本法では, 食品安全委員会の設置やリスク 分析手法の実施などを規定する一方, 食品の安全性の確 保についての基本的な理念 (下図) をまとめている。基本 理念では, 国民の健康保護が最重要との基本的認識の下 に必要な措置が講じられることや，国民の健康への悪影 響が未然に防止されるよう，国際的な動向や国民の意見 に十分配慮しつつ科学的知見に基づき講じられることが 規定されている。さらに, 食品供給行程のあらゆる要素が 食品の安全性に影響を及ぼすおそれがあることから，生 産から消費に至る食品供給行程の各段階で必要な措置が 


\section{食品安全におけるリスク分析手法}

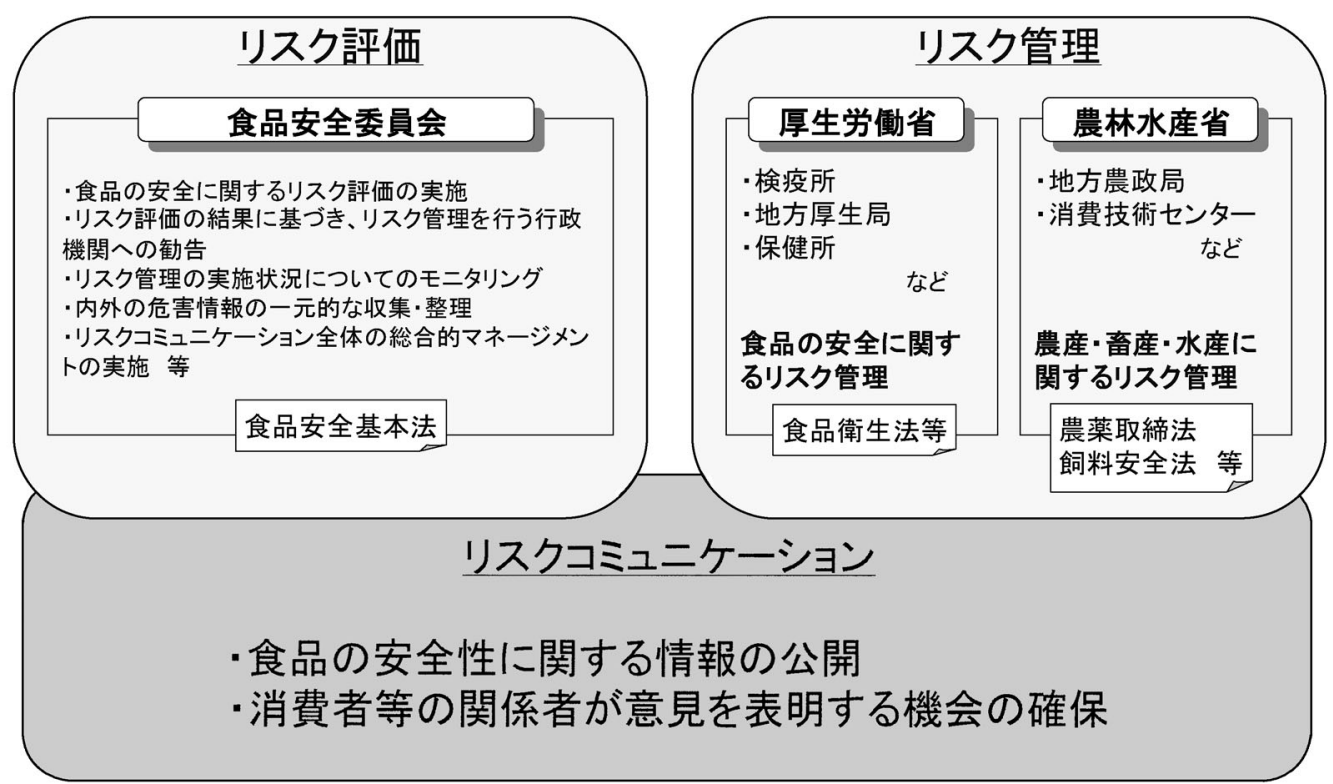

食品の安全性の確保についての基本理念 食品安全基本法 (平成15年法律第48号)

\section{食品の安全性の確保のための措置を講ずる} に当たつての基本的認識

食品の安全性確保のために必要な措置が、国民の健康保護が最重要 との基本的認識の下に講じられることにより行われなければならない。

食品供給行程の各段階における適切な措置 食品供給行程におけるあらゆる要素が食品の安全性に影響を及ぼす おそれがあることにかんがみ、必要な措置が食品供給行程の各段階に おいて適切に講じられることにより行われなければならない。

\section{国民の健康への悪影響の未然防止}

食品の安全性確保に関する国際的な動向や国民の意見に十分配慮しつつ 科学的知見に基づいて講じられることによって、国民の健康への悪影響が 未然に防止されることを旨として、行わなければならない。 
○食中毒発生状況, 特にカンピロバクターによる食中毒 について

厚生労働省では, 毎年都道府県等からの報告を取りま とめ, 食中毒統計を作成している。平成 17 年の食中毒発 生状況（以下）を見ると，ノロウィルスを中心とするウィ ルスを原因とする食中毒が患者数では最多になっている が, 一方では, 従来からある動物性や植物性の自然毒によ
る死者が依然出ていること，サルモネラなどの細菌性食 中毒が未だ多くの被害を出していることが判る。なかで あ, カンピロバクターによる食中毒は件数で全体の約 4 割に達しており，サルモネラなどの他の細菌性食中毒が 近年減少しているなか, 唯一件数及び患者数と屯に増加 する傾向にある。

\begin{tabular}{l}
\multicolumn{5}{|c|}{ 原因物質別食中毒発生状況 (平成 17年) } \\
\hline \\
\hline
\end{tabular}

※: ノロウイルスが274件であった。

カンピロバクター食中毒のうち原因食品が判明してい るものでは, 動物性食品, なかでも加熱不十分な䳕肉など が認められる。厚生労働省では, 鶏肉の安全性を確保する 観点から, 食鳥処理場における HACCP 方式による衛生 管理，流通販売時の温度管理及び食品事業者や消費者向 けのガイドラインや Q\&A などを作成し, 衛生管理の推進 や食中毒予防の注意喚起を進めている。しかしながら, 厚 生労働省が所管する食品衛生法や之畜場法, 食鳥検査法 などの取り組みは, と畜場以降の規制で, 食品の製造加工 から消費の段階に限られている。

近年の国内での調査研究によれば, 農場の時点でカン ピロバクターが認められること, 食鳥処理場での処理で は腸内容物による污染を完全に防ぎ切れないこと, 消費 者の時点で加熱不足などが起こりうることなどが判って きている。
これまでも，獣医公衆衛生分野では，例えば，牛結核な どの対策において, 生産段階での取り組みが行われると ともに, 食肉検査や牛乳の殺菌など食品の製造加工の時 点での取り組みが行われてきた。これは，まさに食品安全 基本法に謳われる基本理念である食品供給行程（フード チェーン）の各段階での食品安全規制の実施にほかなら ない。

カンピロバクターによる食中毒などの課題に対しても, 生産段階での取り組みを推進する立場の農林水産省や都 道府県等農林水産部局, 農畜水産関係事業者などと, 食品 の製造加工，更には消費者の時点での取り組みを推進す る立場の厚生労働省や都道府県等衛生部局, 食品関係事 業者が，様々な形で連携し必要な措置を実施することが 重要である。 


\section{カンピロバクター食中毒を防止するために}

○農場における対策

○食鳥処理場における対策

食鳥処理場におけるHACCP方式による衛生管理

○カット工場、流通·販売時における対策

温度管理、食品の衛生的な取扱い

（食品等事業者が実施すべき管理運営基準に関する指針

(ガイドライン)について)

○食品関係営業者及び消費者に対する普及啓発 カンピロパクター食中毒予防について（Q＆A）

家庭でできる食中毒予防の6つのポイント 